\title{
Pengaruh Pemekaran Wilayah Terhadap Pertumbuhan Ekonomian Daerah (Studi Kasus Tujuh Provinsi Hasil Pemekaran Wilayah Di Indonesia)
}

\section{(The Impact Of The Region Expansion On Regional Economics growth (Study Case Of saven Provinces Result Of Expansion In Indonesia))}

\author{
Wida Safitri, Duwi Yunitasari*, Siti Komariyah \\ Jurusan Ilmu Ekonomi dan Studi Pembangunan, Fakultas Ekonomi dan Bisnis, Universitas Jember (UNEJ) \\ Jln. Kalimantan 37, Jember 68121 \\ E-mail: duwiyunita.feb@unej.ac.id
}

\begin{abstract}
Abstrak
PDRB provinsi hasil pemekaran wilayah menunjukan kenaikan di setiap tahunnya namun perkembangan perekonomian menunjukan sebaliknya. Pendapatan Daerah di Provinsi hasil pemekaran menunjukan adanya kenaikan di setiap tahunnya, namun hal ini tidak terlepas dari tingginya Dana Perimbangan yang didapat dari pemerintah Pusat. Sejak tahun 1999 sampai tahun 2012, di Indonesia terdapat 8 Provinsi yang di mekarkan dan Provinsi Kalimantan Utara di mekarkan pada 2012 akhir. Penelitian ini bertujuan untuk menganalisis dampak pemekaran wilayah terhadap perekonomian di tujuh Provinsi hasil pemekaran di Indonesia dalam kurun waktu 2008 sampai dengan 2017. Data yang digunakan dalam penelitian adalah data sekunder terdiri dari runtut waktu 2008 sampai tahun 2017 yang diperoleh dari Badan Pusat Statistik Nasional. Analisis yang digunakan adalah Indeks Diversitas Entropi PDRB,Indeks Diversitas Entropi Pendapatan Daerah, dan Tipologi Klassen. Dari IDE PDRB terdapat 5 Provinsi yang mengalami perkembangan dan 2 yang belum mengalami perkembangan, Hasil nilai IDE Pendapatan Daerah terdapat 1 Dearah dengan kapasitas fiskal yang tinggi dan 6 lainnya belum mengalami perekembangan. Hasil dari tipologi Klassen terdapat 2 provinsi dengan kategori maju dan tumbuh cepat 4 Provinsi sedang berkembang dan 1 Provinsi relatif tertinggal.
\end{abstract}

Kata Kunci: Pemekaran Wilayah, Tipologi Klassen, Indeks Diversitas Entropi.

\begin{abstract}
Provincial GDP as a result of regional expansion shows an increase in each year but economic development shows differences and Regional Revenues in Provinces resulting from an increase in each year, but this is inseparable from the high Balance Funds obtained from the Central Government. In Indonesia from 1999 to 2012 there were 8 provinces which were expanded and the Province of North Kalimantan was expanded in late 2012. This study aims to analyze the impact of regional expansion on the economy in seven provinces resulting from the expansion in Indonesia in the period 2008 to 2017. The data used in the study are secondary data consisting of sequences from 2008 to 2017 obtained from the National Statistics Agency. The analysis used is the GRDP Entropy Diversity Index, the Regional Revenue Entropy Diversity Index, and the Klassen Typology. From the GRDP IDE there are 5 provinces that have developed and 2 that have not experienced development, the results of the Regional Revenue IDE values are 1 region with high fiscal capacity and the other 6 have not experienced development. The results of the Klassen typology are 2 provinces with advanced and fast growing categories. 4 Provinces are developing and 1 Province is relatively lagging behind.
\end{abstract}

Keywords: Regional Expansions, Tipology Klasen,Indeks Diversitas Entropy.

\section{Pendahuluan}

Kurangnya perhatian dari pemerintah setempat, terutama dalam hal pembangunan mendasari keinginan untuk melakukan pemekaran wilayah Winata (2016). Menurut Rustiadi et al. (2009:32) ada beberapa landasan logis yang harus dijadikan pondasi atau penentu dalam melakukan pemekaran wilayah : (1) Mendekatkan pelayanan kepada masyarakat, dan memberikan kewenangan lebih kepada masyarakat dalam mengelolah potensi daerah; (2) Partisipasi dan rasa memiliki dari rasa masyarakat meningkat; (3) Dapat meningkatkan efisiensi dan produktivitas perekonomian serta menjaga keberlanjutannya ; (4) Dapat meningkatkan akumulasi nilai tambah serta meningkatkan kesejahteraan masyarakat; (5) Menciptakan prinsip keadilan dalam mencapai kesejahteraan.
Otonomi daerah diharapkan mampu mendekatkan fungsi pelayanan birokrasi pemerintahan terhadap rakyat melalui pelayanan publik yang baik guna mempercepat terwujudnya kesejahteraan masyarakat. Setelah penerapan UndangUndang No.32 Tahun 2004 tentang Pemerintahan Daerah, memberikan peluang kepada daerah provinsi, kabupaten, dan kota untuk membentuk daerah pemekaran baru. Pemekaran menjadi kecenderungan baru bagi pembangunan daerah di Indonesia, sejak tahun 1999 sampai dengan 2013 jumlah Provinsi Indonesia dengan adanya 8 provinsi baru yaitu Maluku Utara, Papua Barat, Banten, Kepuluan Bangka Belitung, Gorontalo, Kepulauan Riau, Sulawesi Barat dan Kalimantan Utara maka provinsi di Indonesia menjadi 34 Provinsi.

\footnotetext{
* Corresponding author
} 
Pertumbuhan PDRB di setiap Provinsinya mewujudkan adanya dampak pemekaran, namun hal lainnya juga dapat dilihat jika PDRB yang di hasilkan Provinsi pemekaran cenderung rendah di banding Provinsi lainnya, selain itu ketimpangan yang terjadi antar daerah pemekaran juga sangat tinggi. Pendapatan Daerah disetiap Provinsi juga mengalami kenaikan namun di beberapa daerah terlihat fluktuatif dan Gap antar daerahnya juga sangat tinggi. setelah terjadi pemekaran ada beberapa masalah yang belum teratasi hal ini menunjukan bahawa perlunya analisis kelayakan pemekaran.

Kementerian Dalam Negri R.I (2017) telah menerima 237 proposal untuk pemekaran daerah baru di Indonesia namun karena adanya kendala fiskal, pemekaran daerah baru tertunda. Kemnendagri juga mengungkapkan satu daerah pemerkaran akan memakan biaya lebih dari 300 miliar rupiah. Hal ini membuat pemerintah pusat mengkaji lebih apakah diadakan atau tidaknya pemerkaran daerah. Oleh karena itu hasil dari daerah yang telah di mekarkan harus di analisis untuk mengetahui ada atau tidak manfaat dari pemekaran daerah.

Penelitian ini menggunakan Teori Lokasi yang dikemukakan oleh Weber menurut weber suatu daerah akan cepat berkembang tergantung pada lokasi dan keberadaan sumber daya alam dan sumber daya manusia daerah tersebut.

Tujuan dari Penelitian ini adalah (1) Untuk mengetahui pengaruh pemekaran wilayah terhadap perkembangan sektor ekonomi di Provinsi pemekaran di Indonesia periode 20132017,(2) Untuk mengetahui pengaruh pemekaran wilayah terhadap kapasitas fiskal daerah hasil pemekaran di Indonesia periode 2013-2017. (3) Untuk mengetahui klasifikasi wilayah antar Provinsi hasil pemekaran di tahun 2013-2017.

\section{Metode}

Jenis penelitian ini adalah penelitian kuantitatif. Metode penelitian kuantitatif merupakan suatu cara yang digunakan untuk menjawab masalah penelitian yang berkaitan dengan data berupa angka dan program statistik. Sekaran (2006:160).

\section{Lokasi Penelitian}

Wilayah penelitian ini dilakukan di 7 Provinsi Hasil Pemekaran, yaitu Maluku Utara, Papua Barat, Sulawesi Barat, Banten, Kepulauan Bangka Belitung, Gorontalo, dan Kepulauan Riau. Provinsi Kalimantan Utara juga merupakan Provinsi Hasil Pemekara namun, karena usianya yang masih muda Kalimantan Utara di kecualikan dalam penelitian ini.

\section{Jenis dan Sumber Data}

Jenis data yang digunakan dalam penelitian ini adalah data sekunder yang berupa runtut waktu (times series) dalam bentuk tahunan dengan runtut waktu 10 tahun periode 20082017.

\section{Metode Analisis Data}

\section{Analisis Indeks Diversitas Entropi (IDE)}

Dalam Sayori (2009), nilai indeks diversitas entropy ditujukan untuk menghitung tingkat keberagaman dan keberimbangan aktivitas/sektor ekonomi di suatu wilayah. Semakin bertambah jumlah jenis aktivitas/sektor ekonomi maka nilai indeks diversitas entropi akan semakin besar. Semakin berimbang komposisi berbagai aktivitas/sektor ekonomi tersebut, nilai indeks entropi juga semakin besar, Jika nilai IDE melebihi 1 maka wilayah tersebut semakin berkembang, namun jika nilai IDEnya mendekati 0 maka wilayah tersebut tidak berkembang.

\section{a. Analisis Indeks Diversitas Entropi (IDE) PDRB.}

Analisis ini bertujuan untuk mengetahui perkembangan jenis lapangan usaha sector PDRB sesudah pemekaran adapun sector yang akan diamati meliputi 17 sektor Analisis ini menggunakan formula yang dibangun oleh Saefulhakim (2003) sebagai berikut berikut :

$$
I D E P D R B=-\sum_{i=1}^{n} P i \in P i
$$

Dimana :

Pi = Proporsi sektor-sektor oleh PDRB terhadap total PDRB

$$
\begin{aligned}
\mathrm{n} & =\text { Jumlah Sektor } \\
\mathrm{Pi} & =\frac{X i}{\sum X i} \\
\mathrm{Xi} & =\text { Persentase Masing-Masing Lapangan Usaha } \\
\text { Terhadap Total PDRB } &
\end{aligned}
$$

Untuk menjustifikasikan tingkat perkembangan ekonomi, maka ada ketentuan bahwa jika Indeks Diversitas Entropy (IDE) PDRB semakin tinggi maka tingkat perkembangan ekonomi, semakin tinggi atau semakin merata.

\section{b. Analisis Indeks Diversitas Entropi (IDE) Pendapatan Daerah (PD)}

Analisis ini bertujuan untuk mengetahui perkembangan sumber-sumber pendapatan daerah sesudah pemekaran yang meliputi (1) Pendapatan Asli Daerah (2) Dana Perimbangan, (3) Penerimaan lainnya Analisis ini menggunakan formula yang dibangun oleh) sebagai berikut berikut :

$$
I D E P D=-\sum_{i=1}^{n} P i \in P i
$$

Dimana :

$\mathrm{Pi}=$ Proporsi sumber-sumber PD terhadap total PD

$\mathrm{n}=$ Jumlah Sumber-sumber PD

$P i \quad=\frac{X i}{\sum X i}$

$X i=$ Persentase Masing-Masing Sumber-sumber PD Terhadap PD

Untuk menjustifikasikan tingkat perkembangan, maka ada ketentuan bahwa jika Indeks Diversitas Entropy (IDE) Pendapatan Daerah semakin tinggi maka tingkat perkembangan semakin tinggi atau semakin merata. 
c. Analisis Pertumbuhan Ekonomi Tipology Klassen

Tabel Klasifikasi Daerah Menurut Tipologi Klassen

\begin{tabular}{|c|c|c|c|c|}
\hline & $\mathrm{r}$ & & $\left(y_{i}>\right.$ & $\left(y_{i}<y\right.$ \\
\hline$r_{i}$ & $>$ & $r$ & $\begin{array}{c}\text { Kuadran I } \\
\text { Wilayah Maju } \\
\text { dan Tumbuh } \\
\text { Cepat }\end{array}$ & $\begin{array}{c}\text { Kuadran II } \\
\text { Wilayah Sedang } \\
\text { Tumbuh }\end{array}$ \\
\hline$r_{i}$ & $<$ & $r$ & $\begin{array}{l}\text { Kuadran III } \\
\text { Wilayah Maju } \\
\text { Tapi tertekan }\end{array}$ & $\begin{array}{c}\text { Kuadran IV } \\
\text { Wilayah Relatif } \\
\text { tertinggal }\end{array}$ \\
\hline
\end{tabular}

(Sumber :Sarnowo, 2013)

$$
\begin{array}{ll}
r_{i} & =\text { Tingkat Pertumbuhan PDRB provinsi i } \\
y_{i} & =\text { PDRB perkapita provinsi } \mathrm{i} \\
\mathrm{r} & =\text { Tingkat pertumbuhan PDB } \\
\mathrm{y} & =\text { PDB perkapita wilayah Reverensi }
\end{array}
$$

Keterangan tabel:

1. Kudran I yaitu wilayah maju dan tumbuh cepat, yaitu daerah yang memiliki pendapatan perkapita dan tingkat pertumbuhan ekonomi yang lebih tinggi di banding rata-rata di Provinsi hasil pemekaran.

2. Kuadran II yaitu sedang tumbuh yaitu daerah yang memiliki pendapatan perkapita lebih rendah dari rata-rata, namun memiliki tingkat pertumbuhan ekonomi lebih tinggi dari rata-rata di Provinsi hasil pemekaran.

3. Kuadran III yaitu wilayah maju tapi tertekan, yaitu daerah yang memiliki pendapatan perkapita lebih tinggi di banding rata-rata, tetapi tingkat pertumbuhan ekonominya lebih rendah dibandingkan rata-rata di Provinsi hasil pemekaran.

4. Kuadran IV yaitu wilayah relative tertinggal adalah daerah yang memiliki pendapatan perkapita dan tingkat pertumbuhan ekonomi yang lebih rendah di banding rataratan di Provinsi hasil pemekaran.

\section{Hasil dan Pembahasan}

\section{Hasil}

1. Hasil Analisis Indeks Diversitas Entropi (IDE) PDRB

Tabel 2. Nilai Indeks Diversitas Entropi (IDE) PDRB Tujuh Provinsi Hasil Pemekaran

\begin{tabular}{llllllll}
\hline & & \multicolumn{7}{c}{ Nilai IDE } \\
\hline $\begin{array}{lllllll}\text { Tahu } \\
\mathbf{n}\end{array}$ & $\begin{array}{l}\text { Maluku } \\
\text { Utara }\end{array}$ & $\begin{array}{l}\text { Papua } \\
\text { Barat }\end{array}$ & $\begin{array}{l}\text { Bante } \\
\mathbf{n}\end{array}$ & $\begin{array}{l}\text { Bangka } \\
\text { Belitung }\end{array}$ & Gorontalo & $\begin{array}{l}\text { Kep } \\
\text { Riau }\end{array}$ & $\begin{array}{r}\text { S } \\
\mathbf{u}\end{array}$ \\
\hline 2008 & 1,894 & 2,081 & 1,687 & 2,031 & 2,181 & 1,673 & 1 \\
2009 & 1,895 & 2,095 & 1,733 & 2,048 & 2,195 & 1,690 & 1 \\
2010 & 1,897 & 1,983 & 1,750 & 2,057 & 2,211 & 1,686 & 1 \\
2011 & 1,937 & 1,859 & 1,765 & 2,072 & 2,214 & 1,690 & 1 \\
2012 & 2,192 & 1,950 & 2,141 & 2,175 & 2,139 & 1,962 & 2 \\
2013 & 2,197 & 1,963 & 2,127 & 2,193 & 2,143 & 1,953 & 2 \\
2014 & 2,204 & 1,985 & 2,154 & 2,207 & 2,148 & 1,954 & 2 \\
2015 & 2,215 & 2,005 & 2,167 & 2,212 & 2,174 & 1,955 & 2
\end{tabular}

\begin{tabular}{cccccccc}
2016 & 2,228 & 2,020 & 2,183 & 2,222 & 2,164 & 1,967 & 2 \\
2017 & 2,242 & 2,038 & 2,192 & 2,234 & 2,153 & 2,003 & 2 \\
$\begin{array}{r}\text { rata } \\
\text { rata }\end{array}$ & $\mathbf{2 , 0 9 0}$ & $\mathbf{1 , 9 9 8}$ & $\mathbf{1 , 9 9 0}$ & $\mathbf{2 , 1 4 5}$ & $\mathbf{2 , 1 7 2}$ & $\mathbf{1 , 8 5 3}$ & $\mathbf{1}$ \\
\multicolumn{2}{l}{ Sumber : Data Diolah (2019) } & & &
\end{tabular}

2. Hasil Analisis Indeks Diversitas Entropi (IDE) Pendapatan

\begin{tabular}{|c|c|c|c|c|c|c|c|}
\hline \multirow[b]{2}{*}{ Tahun } & \multirow[b]{2}{*}{$\begin{array}{c}\text { Maluku } \\
\text { Utara }\end{array}$} & \multicolumn{6}{|c|}{ Nilai IDE } \\
\hline & & $\begin{array}{l}\text { Papua } \\
\text { Barat }\end{array}$ & Banten & $\begin{array}{c}\text { Bangka } \\
\text { Belitung }\end{array}$ & $\begin{array}{c}\text { Goron } \\
\text { talo }\end{array}$ & $\begin{array}{l}\text { Kep } \\
\text { Riau }\end{array}$ & $\mathrm{S}$ \\
\hline 2008 & 0,525 & 0,840 & 0,615 & 0,648 & 0,665 & 0,610 & 0 \\
\hline 2009 & 0,340 & 0,765 & 0,626 & 0,618 & 0,476 & 0,575 & 0 \\
\hline 2010 & 0,441 & 0,820 & 0,584 & 0,673 & 0,681 & 0,652 & 0 \\
\hline 2011 & 0,745 & 0,823 & 0,553 & 0,781 & 0,676 & 0,663 & 0 \\
\hline 2012 & 0,777 & 0,831 & 0,919 & 0,891 & 0,837 & 0,827 & 0 \\
\hline 2013 & 0,774 & 0,802 & 0,921 & 0,885 & 0,813 & 0,817 & 0 \\
\hline 2014 & 0,783 & 0,864 & 0,829 & 0,871 & 0,849 & 0,862 & 0 \\
\hline 2015 & 0,780 & 0,864 & 0,846 & 0,896 & 0,847 & 0,946 & 0 \\
\hline 2016 & 0,789 & 0,858 & 0,665 & 0,940 & 0,609 & 0,967 & 0 \\
\hline 2017 & 0,868 & 0,875 & 0,685 & 0,627 & 0,520 & 0,647 & 0 \\
\hline $\begin{array}{l}\text { rata } \\
\text { rata }\end{array}$ & 0,682 & $\mathbf{0 , 8 3 4}$ & 0,724 & 0,783 & 0,697 & 0,757 & o \\
\hline
\end{tabular}
Daerah

Tabel 3. Nilai Indeks Diversitas Entropi (IDE) Pendapatan Daerah Tujuh Provinsi Hasil Pemekaran

\begin{tabular}{|c|c|c|}
\hline & $\mathbf{y i}>\mathbf{y}$ & $\mathbf{y i}<\mathbf{y}$ \\
\hline \multirow[t]{5}{*}{$\mathbf{r i}>\mathbf{r}$} & $\begin{array}{l}\text { Maju dan Tumbuh } \\
\text { cepat }\end{array}$ & Sedang Tumbuh \\
\hline & Papua Barat & Maluku Utara \\
\hline & Kepulauan Riau & Banten \\
\hline & & Gorontalo \\
\hline & & Sulawesi Barat \\
\hline \multirow[t]{2}{*}{$\mathbf{r i}<\mathbf{r}$} & Maju Tapi tertekan & Relatif Tertinggal \\
\hline & & Kepulauan Bangka Belitung \\
\hline
\end{tabular}

3. Hasil Analisis Tipology Klasen

Tabel 4. Klasifikasi Wilayah Menurut Tipologi Klasen

Sumber : Data Diolah(2019)

\section{Pembahasan}

\section{Perkembangan Struktur Perekonomian dan Kapasitas Fiskal}

\section{Provinsi Maluku Utaara}

a. Perkembangan Struktur Perekonomian Wilayah.

Pertumbuhan dan Perkembangan struktur perekonomian suatu wilayah didekati dengan data Produk Domestik Regional Bruto (PDRB). Nilai Indeks Diversitas Entropi (IDE) mencerminkan tingkat perkembangan sektor-sektor perekonomian di Provinsi Maluku Utara setelah terjadi pemekaran. Tingkat perkembangan sektor perekonomian dapat di katakan baik karena nilai IDE PDRB Provinsi Maluku Utara di atas 1, selain itu setelah terjadinya pemekaran banyak sektor-sektor perekonomian yang 
menguat dari tahun ke tahunnya dan mulai memberikan kontribusi terhadap perekonomian Provinsi Maluku Utara.

\section{b. Perkembangan Kapasitas Fiskal}

Hasil IDE Provinsi Maluku Utara yang terdapat pada Tabel 3 setelah pemekaran mengalami kenaikan yang positif walaupun nilainya berada di bawah angka 1, hal ini menunjukan bawah Kapasitas Fiskal Provinsi Maluku Utara masih bergantung pada Dana Perimbangan yang memberikan kontribusi besar terhadap pendapatan daerah. Walaupun pendapatan asli daerah menunjukan penguatan di setiap tahunnya hal ini tidak dapat menutupi bahwa ketergantungan Dana Perimbangan dari pemerintah jumlahnya masih sangat besar.

\section{Provinsi Papua Barat}

\section{a. Perkembangan Struktur Perekonomian Wilayah}

Tingkat perkembangan struktur perekonomian Provinsi Papua Barat dapat dikatakan baik karena nilai IDE PDRB Provinsi Papua Barat di atas 1. Namun pertumbuhan di setiap tahunnya pasif dan cenderung menurun di banding tahun-tahun sebelumnya. Nilai IDE Pada tahun 2017 bahkan nilainya lebih kecil di banding tahun 2008 hal ini menunjukan bahwa sektor-sektor perekonomian di Provinsi Papua Barat selama 10 tahun terakhir belum mengalami perkembangan.

\section{b. Perkembangan Kapasitas Fiskal}

bahwa Kapasitas Fiskal Provinsi Papua Barat belum mengalami perkembangan, nilai IDE Pendapatan Daerah tumbuh pasif cenderung stagnan, Pertumbuhan Nilai IDE yang fluktuatif mencerminkan keadaan pendapatan daerah yang juga tumbuh fluktuatif, hal ini menunjukan lemahnya kinerja pemerintah dalam mengolah sumber-sumber pendapatan daerah dan lemahnya kapasitas fiskal Provinis Papua Barat.

\section{Provinsi Banten}

a. Perkembangan Struktur Perekonomian Wilayah.

Nilai Indeks Diversitas Entropi (IDE) dapat dikatakan baik karena melebihi angka 1. Nilai Indeks Diversitas Entropi (IDE) mencerminkan tingkat perkembangan sektor-sektor perekonomian di Provinsi Papua Barat setelah terjadi pemekaran. Nilai IDE Provinsi Banten selalu melebihi angka 1 menggambarkan bahwa terdapat perkembangan pada sektor ekonominya. Pertumbuhan nilai IDE secara signifikan dari tahun ke tahun mengambarkan bahwa sektor-sektor perekonomian di Provinsi Banten mengalami perkembangan saat setalah pemekaran.

\section{b. Perkembangan Kapasitas Fiskal}

Nilai IDE Provinsi Banten yang ada pada gambar 3 yang tumbuh fluktuatif, hal ini di sebabkan oleh laju sumbersumber Pendapatan Daerah yang tidak menentu di setiap tahunnya. Namun jika di bandingkan dengan Provinsi lain Kapasitas Fiskal Provinsi Banten Masih dikatakan cukup baik Karena pembangunan daerah Provinsi Banten di danai oleh dana daerah yang berasal dari PAD Provinsi Banten. Namun pada Nilai IDE Provinsi Banten yang ada pada tabel 3 mengalami 4 kali penurunan dalam sebuluh tahun yaitu pada tahun 2010,2011,2014 dan 2015 yang menunjukan bahwa kinerja pemerintah daerah dalam menjaga kestabilan kapasitas fiskal di Provinsi Barat dinilai masih kurang.

\section{Provinsi Kepulauan Bangka Belitung}

\section{a. Perkembangan Struktur Perekonomian Wilayah}

Nilai IDE Provinsi Kepulauan Bangka Belitung terus menglami kenaikan yang signifikan, Sejak tahun 2008 sampai tahun 2017 nilai IDE Provinsi Bangka Belitung tidak pernah mengalami penurunan, hal ini menggambarkan bahwa setelah terjadi pemekaran sektor-sektor perekonomian di Provinsi Kepulauan Bangka Belitung terus mengalami perkembangan yang positif.

\section{b. Perkembangan Kapasitas Fiskal}

Nilai IDE pendapatan daerah Provinsi Kepulauan Bangka Belitung tumbuh fluktuatif, nilai IDE pendapatan daerah mengalami penurunan sebanyak 4 kali yaitu di tahun $2009,2013,2014$ dan 2017. Nilai IDE pendapatan daerah yang fluktuatif di sebabkan pertumbuhan proporsi sumber-sumber pendapatan daerah yang fluktuatif juga, hal ini menunjukan bahwa kinerja pemerintah daerah dalam mengelolah sumbersumber pendapatan daerah terus menurun dari tahun ke tahun.

\section{Provinsi Gorontalo}

\section{a. Perkembangan Struktur Perekonomian Wilayah.}

Nilai Indeks Diversitas Entropi (IDE) mencerminkan tingkat perkembangan sektor-sektor perekonomian di suatu daerah, pada gambar 2 menjelaskan bahwa nilai IDE Provinsi Gorontalo setelah terjadi pemekaran, nilai IDE Provinsi gorontalo mengalami pertumbuhan yang pasif dan fluktuatif, hal ini menggambarkan bahwa sektor-sektor ekonomi di Provinsi Gorontalo belum mengalami perkembangan setelah terjadi pemekaran. Kinerja pemerintah daerah dinilai lemah dalam meningkatkan sektor perekonomian.

\section{b. Perkembangan Kapasitas Fiskal}

Nilai IDE Provinsi Gorontalo juga mengalami pertumbuhan yang fluktuatif selama 10 tahun terakhir terjadi 6 kali penurunan yaitu pada tahun 2009,2011, 2013,2015,2016 dan 2017, yang menadakan bahwa lemahnya kapasitas fiskal Provinsi Gorontalo setelah terjadi pemekaran. Selain itu Dana perimbangan yang mendominasi pendapatan daerah menadakan bahwa Provinsi Gorontalo masih memiliki ketergantung terhadap pemerintah pusat untuk dana pembangunan daerahnya.

\section{Provinsi Kepulauan Riau}

\section{a. Perkembangan Struktur Perekonomian Wilayah.}

Nilai IDE PDRB menggambarkan perkembangan sektorsektor ekonomi suatu daerah jika Nilai IDE PDRB semakin tinggi maka sektor-sektor perekonomian di daerah tersebut mengalami perkembangan. Tabel 2 menjelaskan pertumbuhan nilai IDE Kepulauan Riau, Nilai IDE Kepulauan Riau dapat dikatakn cukup baik karena melebihi angka 1. Tabel 2 juga menjelaskan nilai IDE Provinsi Kepulauan Riau pernah mengalami penurunan sebanyak dua kali yaitu di tahun 2010 dan di tahun 2013. . Secara keseluruhan nilai IDE Provinsi Kepulauan Riau menunjukan bahwa sektor-sektor perekonomian Provinsi Kepulauan Riau mengalami perkembang saat setelah terjadi pemekaran. 


\section{b. Perkembangan Kapasitas Fiskal}

IDE Pendapatan Daerah Provini kepulauan Riau yang berada di gambar 3, yang juga mengalami pertumbuhan yang fluktuatif, nilai IDE Provinsi Kepulauan Riau mengalami 3 kali penurunan yaitu pada tahun 2009,2013 dan 2017. Meskipun tumbuh fluktuatif, hal yang perlu di perhatikan adalah selama 10 tahun terakhir Kepulauan Riau rata-rata menyumbang 32\% untuk pembangunan daerahnya dapat dikatakan, kapasitas fiskal Provinsi Kepulauan Riau dikatakan cukup baik hanya saja kinerja pemerintah yang kurang maksimal dalam mengelolah sumber-sumber pendapatan daerah.

\section{Provinsi Sulawesi Barat}

\section{a. Perkembangan Struktur Perekonomian Wilayah}

kenaikan sektor-sektor Provinsi Sulawesi Barat di katakan sangat lambat, hal ini juga terlihat pada hasil IDE PDRB pada gambar 2 Nilai IDE Provinsi Sulawesi Barat dapat dikatakan cukup baik karena di atas angka 1, hal yang perlu diperhatikan adalah bahwa, lambatnya nilai IDE juga mengambarkan lambatnya perkembangan sektor perekonomain di Provinsi Sulawesi barat. Hal ini juga menggabarkan lambatnya kinerja pemerintah daerah dalam meningkatkan sektor-sektor perekonomian.

\section{b. Perkembangan Kapasitas Fiskal}

Nilai IDE Provinsi Sulawesi Barat terjadi penurunan sebanyak 3 kali yaitu pada tahun 2009, 2015 Pertumbuhan sumber-sumber pendapaan daerah yang fluktuatif dan juga dominasi dana perimbang di Provinsi Sulawesi Barat menunjukan bahwa lemahnya kapasitas fiskal Provinsi Sulawesi Barat setelah terjadinya pemekaran.

Menurut penelitian yang di lakukan Sayori (2009) bahwa pengaruh pemekaran wilayah belum memberikan dampak secara positif terhadap pertumbuhan sektor ekonomi dan kapasitas fiskalnya di Kapubapten Raja Ampat namun cenderung mengalami peningkatan perkembangan wilayah. Sedangkan menurut menurut (Malia, 2009), setelah di adakannya pemekaran Kabupaten Cimahi mengalami perkembangan yang signifikan pada pertumbuhan ekonomi dan kesejahteraan masyarakat.

\section{Klasifikasi Wilayah Menurut Tipologi Klassen}

Provinsi Hasil Pemekaran di bagi manjadi 4 klasifikasi sesuai dengan tipologi klassen Provinsi Papua Barat dan Provinsi Kepulauan Riau Termasuk Provinsi Maju dan Tumbuh Cepat. Provinsi Maluku utara, Provinsi Banten, Provinsi Gorontalo, Provinsi Sulawesi Barat adalah Provinsi yang sedang tumbuh. Sedangkan yang termasuk dalam kategori daerah relative tertinggal adalah Provinsi Kepulauan Bangka Belitung.

\section{Simpulan}

1. Pengaruh pemekaran terhadap dapat dilihat secara nyata, terdapat 5 Provinsi yang menunjukan adanya perkembangan setelah terjadi pemekaran yaitu Provinsi Maluku Utara, Provinsi Banten, Provinsi Kepulauan Bangka Belitung, Provinsi Kepulauan Riau dan Provinsi Sulawesi barat terjadi pemekaran. Sedangakan pengaruh pemekaran belum terlihat di Provinsi Papua Barat dan Provinsi Gorontalo yang belum terlihat perkembangan sektor-sektor perekonomiannya.

2. Setelah terjadi pemekaran Kapasitas Fiskal pada ke tujuh Provinsi hasil pemekaran belum terlihat. Terdapat Provinsi dengan kapitas fiskal yang tinggi yaitu Provisi Banten. Sedangkan 6 Provinsi lainnya belum menunjukan adanya peningkatan pada kapasitas fiskal daerahnya, hal ini terbukti bahwa dana perimbangan masih mendominasi di 6 Provinsi tersebut. Oleh karena itu dampak terhadinya pemekaran belum terlihat terhadap kapasitas fiskal Provinsi hasil pemekaran di Indonesia.

3. Berdasarkan tipologi klassen Provinsi hasil pemekaran dapat diklasifikasikan berdasarkan pertumbuhan ekonomi menjadi tiga kelompok yaitu wilayah maju dan tumbuh cepat yaitu Provinis Kepulauan Riau dan Provinsi Papua Barat. Wilayah sedang tumbuh terdapat empat Provinsi yaitu Provinsi Maluku Utara, Provinis Banten, Provinsi Gorontalo, dan Provinis Papua Barat, dan wilayah relative tertinggal adalah Provinsi Kepulauan Bangka Belitung.

Pemekaran wialayah yang dilaksanakan di Indonesia jangan hanya bertujuan untuk memperoleh Dana Perimbangan dari Pemerintah pusat, namun juga harus dapat meningkatkan perekonomian di setiap wilayah pemekaran.

\section{Referensi}

Kementerian Dalam Negri R.I. (n.d.). Retrieved March 7, 2020, from https:/www.kemendagri.go.id/berita/baca/13737/khawatirkan-fiskalmendagri-tunda-usulan-pemekaran-daerah

Malia, R. (2009). Analisis Dampak Pemekeran Wilayah Terhadap Pembangunan Ekonomi Daerah (Studi Khasus Chimahi Provinsi Jawa Barat). Institut Pertanian Bogor.

Rustiadi, E., Saefulhakim, S., \& Panuju, D. R. (2009). Perencanaan dan Pengembangan Wilayah (W. Mutaqin (Ed.)). Yayasan Obor. https://www.researchgate.net/publication/318016427_Perencanaan_da n_Pengembangan_Wilayah

Sayori, N. (2009). Analisis Dampak Pemekaran Wilayah Terhadap Perekonomian Wilayah Kepulauan Dan Pengembangan Pariwisata Bahari (Studi Kasus Di Kabupaten Raja Ampat, Provinsi Papua Barat). Institut Pertanian Bogor.

Sekaran, U. (2006). Metodologi Penelitian untuk Bisnis 1 Edisi 4. Salemba Empat.

Winata, G. A. (2016). Dampak Pemekaran Wilayah Terhadap Perkembangan Perekonomian Dan Kinerja Pemerintah Daerah Kota/Kabupaten Di Provinsi Banten. In Intergovernmental Panel on Climate Change (Ed.), Departemen Ilmu Ekonomi Fakultas Ekonomi Dan Manajemen Institut Pertanian Bogor. Cambridge University Press. 